\title{
INTESTINAL PROTEIN ABSORPTION IN MALNOURISHED MICE WITH ACUTE SCHISTOSOMIASIS MANSONI
}

\author{
HAROLDO S. FERREIRA; ERIDAN M. COUTINHO*/+; NAIDE R. TEODÓSIO**; \\ CLAUDIA L. CAVALCANTI \& MARIA DE JESUS A. SAMICO*
}

\begin{abstract}
Universidade Federal de Alagoas, Maceió, AL, Brasil *Centro de Pesquisas Aggeu Magalhães/FIOCRUZ Caixa Postal 7472, 50670-420 Recife, PE, Brasil **Universidade Federal de Pernambuco, Departamento de Nutrição do Centro de Ciências da Saúde, Recife, PE, Brasil
\end{abstract}

Intestinal protein absorption was studied in undernourished albino Swiss mice with acute schistosomiasis mansoni. Undernutrition was induced by feeding mice with the Regional Basic Diet (RBD) ingested by human populations in Northeast Brazil, an experimental model previously developed in our laboratory. Weaning mice were infected with 40 cercariae and compared to undernourished non-infected mice and/or to infected mice fed a balanced control diet. Apparent and True Protein Absorption Coefficients were determined by nitrogen balance studies during five consecutive days ending at the 63rd day of the trial (acute phase of murine schistosomiasis). Fecal metabolic nitrogen (FMN) was determined after administration of a nonprotein diet and was also calculated through linear regression. Our results showed a reduced protein absorption in non-infected RBD-fed mice as compared to mice fed a casein control diet. Infection with Schistosoma mansoni had apparently no effect on intestinal protein absorption in well-nourished mice. However, infection seemed to interfere with protein absorption in undernourished animals, since the lowest absorption ratios have been detected among RBD-fed infected mice. A brief discussion is made on the advantages of using the method of linear regression for the determination of FMN.

Key words: schistosomiasis mansoni - protein absorption - mice - malnutrition

Malnutrition and schistosomiasis infection are relevant public health problems in Northeast Brazil, and the overlap of both conditions in the same geographical areas makes interesting the study of these interrelationships, as they develop on a common epidemiological background (Coutinho, 1976). Parasitic infections in general represent one of the most important causative factors of low food biological utilization. Thus it can affect the nutritional status of human populations. In the past, several papers have focused on aspects of the interrelationships between malnutrition and schistosomiasis. However, in most of these

This work received support from Conselho Nacional de Pesquisas and Fundaçào de Amparo à Pesquisa de Pernambuco (FACEPE).

Part of this investigation was submitted to the Universidade Federal de Pernambuco (Brazil) by the senior author, in partial fulfillment of the requirements for the degree of Master in Sciences.

${ }^{+}$Corresponding author.

Received 17 February 1993.

Accepted 23 August 1993. publications purified and/or semi-synthetic diets have been used (De Witt, 1957a; Coutinho et al., 1962; Knauft \& Warren, 1969; Akpom \& Warren, 1975). Malnutrition induced by feeding mice with the Regional Basic Diet (RBD), usually ingested by human populations, appears to be a model closer to what is seen in human communities living in endemic foci of schistosomiasis mansoni in Northeast Brazil (Coutinho, 1976, 1980; Teodósio et al., 1990). The effects of malnutrition induced by RBD feeding have been studied in different pathological and physiopathological conditions (Coutinho, 1976, 1980; Guedes et al., 1987; Silva et al., 1987; Lago et al., 1988; Teodósio et al., 1990; Coutinho et al., 1991, 1992).

Previous investigations on intestinal absorption in malnutrition (Holcmans \& Lambrechts, 1955; Lee \& Chow, 1965; Adibi, 1970; WalkerSnith \& McNeish, 1989), as well as in the hepato-splenic clinical stage of schistosomiasis mansoni (El-Rooby et al., 1963; Fikry, 1963; Fikry et al., 1966; Mott et al., 1971; Pucci et al., 1978; Nigro et al., 1984; Machado, 1988) 
have detected some impairment in intestinal absorption occurring in both conditions. However, data regarding the pathogenesis and intensity of this disfunction in the malnourished host infected with Schistosoma mansoni are still lacking. The use of different experimental designs may account for the incomplete and somewhat conflicting results on the relationship between nutrition and schistosomiasis.

The aim of the present investigation was to study the intestinal protein absorption in undornourished mice infected with $S$. mansoni (acute stage of the disease), as a severe malabsorption syndrome is likely to develop in both conditions, leading to undesirable alterations of the nutritional status of the host.

\section{MATERIALS AND METHODS}

Animals - Male weaning ( 21 days old) albino Swiss mice, weighing 10 to $15 \mathrm{~g}$ were used. They were housed in individual stainless-steel wire mesh metabolic cages and maintained at $23 \pm 2{ }^{\circ} \mathrm{C}$ with a $12 \mathrm{hr}$ light $/ 12 \mathrm{hr}$ dark cycle. The animals were weighed once a week.

Diet - The experimental diet used was the Regional Basic Diet from Northeast Brazil (RBD). It is based on human staple foods usually ingested by human populations in the following proportions $(\mathrm{g} / 100 \mathrm{~g})$ : kidney beans - Phaseolus vulgaris, 18.34; manioc flour Manihot esculenta, 64.81; fat-poor dried and salted meat 3.74, dried and salted meat fat 0.35 and sweet potato - Iponaea batatas, 12.76. The composition of RBD is as follows $(\mathrm{g} / 100 \mathrm{~g})$ : $7.87 \%$ proteins, $69.67 \%$ carbohydrates, $0.80 \%$ fats, $1.26 \%$ minerals, $7.21 \%$ fibers and $13.19 \%$ humidity. Details concerning RBD percentage composition and preparation have been described in previous papers (Coutinho, 1976; Teodósio et al., 1990).

The control diet had the following composition $(\mathrm{g} / 100 \mathrm{~g})$ : commercial casein 27.08 ; vegetable oil 7.50; corn starch 57.42; cellulose 2.00 . This diet was supplemented with mineral salts (4.00) and vitamin mixtures (1g watersoluble and $\mathrm{lg}$ fat - soluble vitamins), according to Tagle \& Donoso (1965).

A non-protein diet was given to 10 mice fed RBD and 10 mice fed the control (casein) diet, after 63 days of the trial, for determination of the fecal metabolic nitrogen (FMN). It was composed as follows $(\mathrm{g} / 100 \mathrm{~g})$ : corn starch 84.00 (proteins 0.80 ; carbohydrates 73.80 ; fat 0.20 ; minerals 0.10 ); vegetable oil 8.00 (fat 8.00 ) and cellulose (fibers 2.00). Mineral salts $(4.00)$, fat-soluble and water-soluble vitamin mixtures were added as in the control diet.

All diets were given to the mice in pellet form.

Infection - A S. mansoni strain isolated from São Lourenço da Mata (Pernambuco State. Brazil) and maintained regularly in our laboratory was used. Each mouse was infected percutaneously with 40 cercariae shed from Biomphalaria glabrata reared and infected in the laboratory.

Studies on intestinal absorption - Intestinal protein absorption was studied in the four groups of animals, sixty days after infection with $S$. mansoni. Total dietary nitrogen was determined by Kjedahl's micro-method and the results were multiplied by 6.25 to calculate the amount of protein in the diet of each group ( $100 \mathrm{~g}$ of protein contains $16 \mathrm{~g}$ of nitrogen and $1 \mathrm{~g}$ of nitrogen is equivalent to $6.25 \mathrm{~g}$ of protein). Total food consumption and protein intake were determined during the five days of studies on intestinal absorption. Sheets of filter paper were placed on trays under the metabolic cages, to ensure urine absorption and thus minimize the chance of contamination of mouse stools with urinary nitrogen. At the end of the experimental period (five consecutive days), the stools were collected, dried in an oven at $105^{\circ} \mathrm{C}$ until reaching a constant weight. Quantification of the fecal nitrogen (FN) was made by Kjedahl's micro-method and the percentage of the absorbed nitrogen (nitrogen intake-fecal nitrogen) was calculated as below:

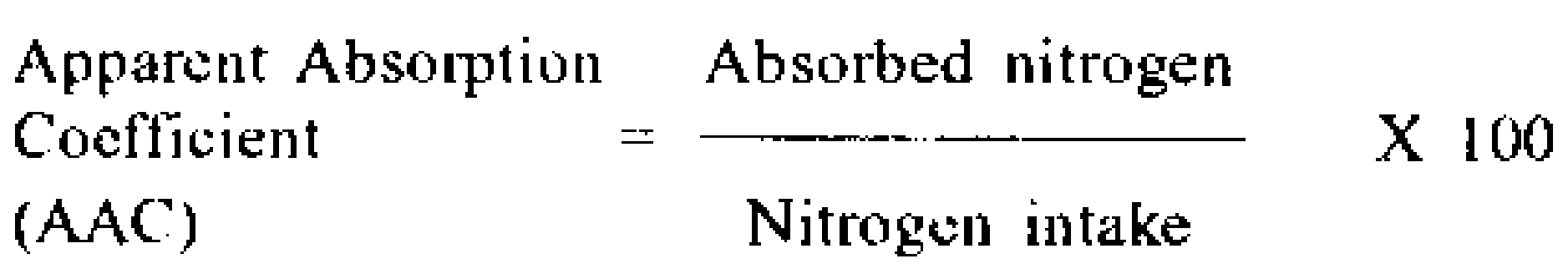

The True Absorption Coefficient (TAC) was determined by subtracting the fecal metabolic nitrogen (FMN) from the absorbed nitrogen. FMN was determined in nine RBD-fed mice (three infected and six non-infected ones) and in ten casein-fed control animals (five infected and five non-infected mice). To these animals, a non-protein diet was given for six days (1 day for adaptation to the diet and five days for the course of the assay, during which the mice 
had their stools collected for chemical determination of the FMN. The TAC was calculated as below:

$\begin{aligned} & \text { True Absorption Nitrogen intake }-(F N-F M N) \\ & \text { Coefficient } \\ & (\text { TAC })\end{aligned}=\frac{\text { Nitrogen intake }}{\text { a }}=100$

The FMN was also calculated by linear regression, as proposed by Holemans \& Lambrechts (1955). According to this method, numbers corresponding to the different levels of protein intake are plotted versus the fecal nitrogen (determined for each animal in each group) on a scatter diagram with extrapolation to the point of zero protein intake.

Experimental protocol - After weaning, mice were maintained in individual metabolic cages and kept free from infection for three days. The body weight was registered weckly. After this adaptation period, the animals were divided into four groups of 10 mice each: RBD infected, RBD non-infected, Control (casein) infected and Control (casein) non-infected. The experiment lasted 63 days. Mice were screened for Schistosoma infection through stool examination and submitted to nitrogen balance studies for five consecutive days. Food and protein intakes were then recorded. They were sacrificed by exsanguination under light ether anaesthesia, and their livers were examined to check for the presence of parasites and/or eggs.

Statistical analysis - The analysis of variance and Duncan's range test were used, proportions being compared by normal approximation. The probability level considered significant was $\mathrm{p}<0.05$.

\section{RESULTS}

The mean body weight of RBD-fed infected mice was always lower than that of casein-fed infected animals. Yet the weight curve of RBDfed non-infected mice was lower as compared to the casein-fed non-infected animals. However, RBD-fed groups did not show marked differences between infected and non-infected mice regarding body weights (Figs 1A, 1B).

Determinations of food consumption and protein intake, as well as of fecal protein excretion measured during the five consecutive days of nitrogen balance studies, are recorded in Table I. Control animals showed higher food and protein intakes as compared to RBD-fed mice. Influence of $S$. mansoni infection was observed on undernourished animals, which showed the lowest values regarding protein intake and fecal protein excretion.

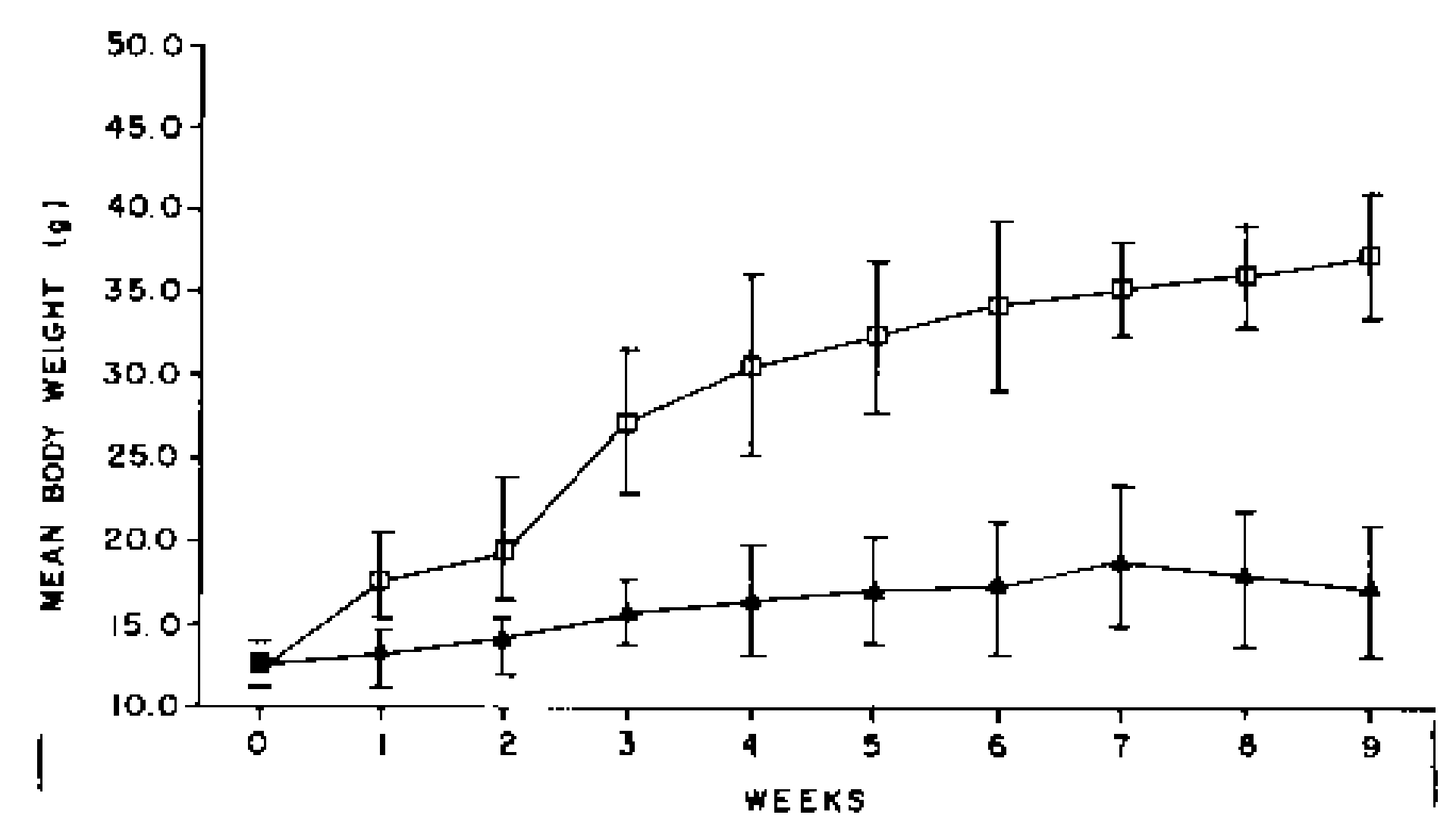

Fig. 1A: weight curves of infected (Schistosoma mansoni) mice fed Regional Basic Diet and control diets. $\square$ arithmetic mean (Control diet); $\boldsymbol{A}$ arithmetic mean (Regional Basic Diet); I lower and upper limits.

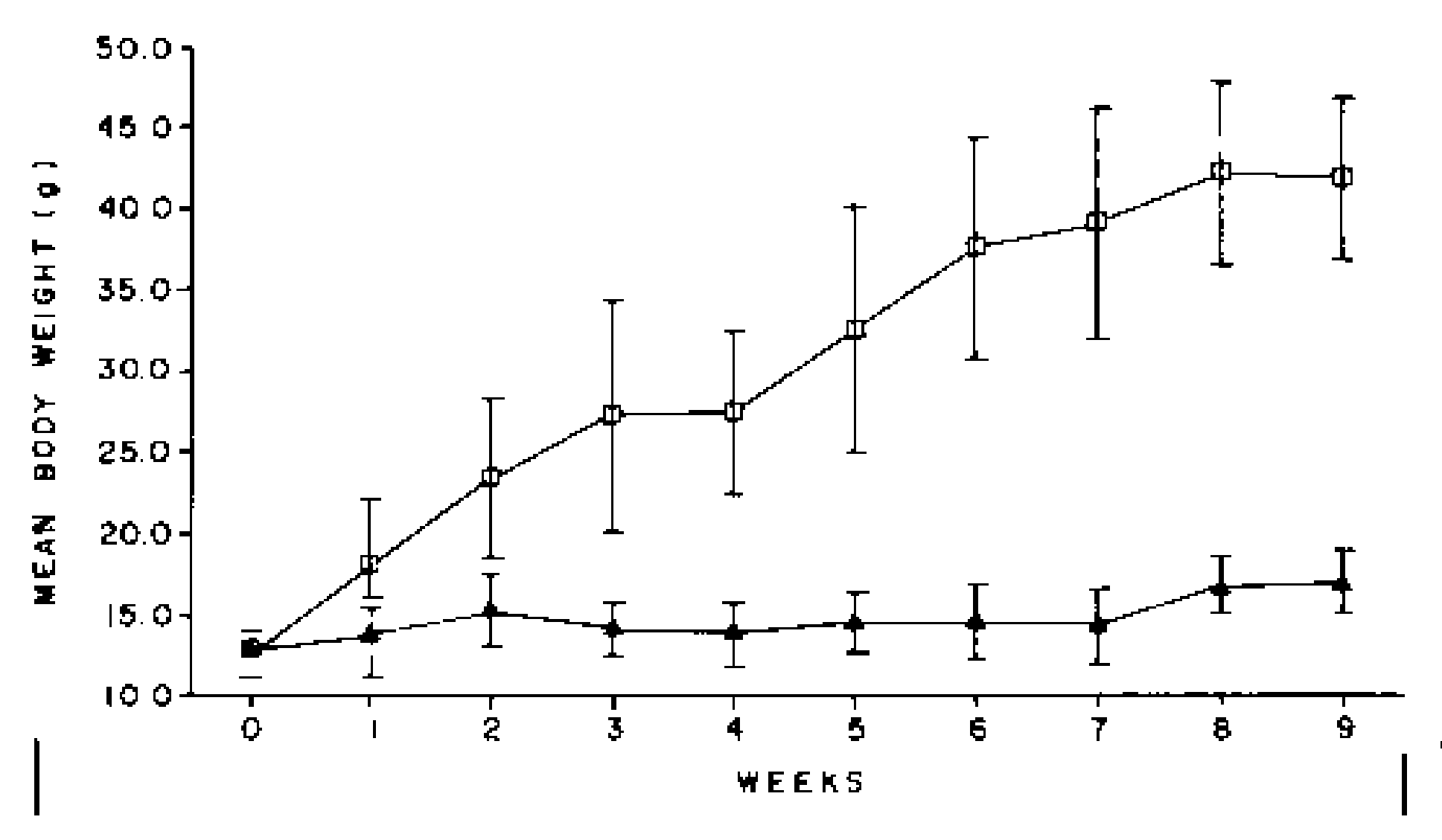

Fig. 1B: weight curves of uninfected (Schistosoma mansoni) mice fed Regional Basic Diet and control diets. $\checkmark$ arithmetic mean (Control diet); $\boldsymbol{\Delta}$ arithmetic mean (Regional Basic Diet); I lower and upper limits.

AAC and TAC (in both non-protein feeding and linear regression calculation methods) did not differ significantly between infected and non-infected mice, in casein-fed groups. However, undernourished RBD-fed mice showed lower protein absorption ratios as compared to their controls, the lowest values being observed in infected animals. This difference could be detected when the TAC was calculated through linear regression (Table II).

Regarding the FMN it was found that when the non-protein feeding assay was performed, cascin-fed infected mice excreted FMN almost twice as much as casein non-infected animals and this difference was statistically significant. No significant difference could be detected between infected and non-infected RBD-fed mice, by using the above mentioned assay. The linear regression method showed no difference 


\section{TABLE I}

Food consumption, protein intake and fecal protein excretion in RBD-fed (undernourished) and control mice, infected or not with Schistosoma mansoni, during five consecutive days of nitrogen balance studies

\begin{tabular}{lcccr} 
Groups & Number of mice & $\begin{array}{c}\text { Food consumption } \\
(\mathrm{g}) \\
(\overline{\mathrm{X}} \pm \mathrm{SD})\end{array}$ & $\begin{array}{c}\text { Protein intake } \\
(\mathrm{g})\end{array}$ & $\begin{array}{c}\text { Fecal protein } \\
\text { excretion }(\mathrm{g}) \\
(\overline{\mathrm{X}} \pm \mathrm{SD})\end{array}$ \\
\hline Control & 10 & 11,30 & $(\overline{\mathrm{X}} \pm \mathrm{SD})$ & 0,35 \\
(non-infected & & $\pm 5,50$ & 2,86 & $\pm 0,20$ \\
Control & 10 & 14,58 & $\pm 1,40$ & 0,53 \\
(infected) & 10 & $\pm 4,41$ & $\pm 1,69$ & $\pm 0,27$ \\
RBD & & 8,94 & 0,79 & 0,42 \\
(non-infected) & 10 & $\pm 2,86$ & $\pm 0,25$ & $\pm 0,10$ \\
RBD & & 4,59 & 0,43 & 0,32 \\
(infected) & & $\pm 2,59$ & $\pm 0,23$ & $\pm 0,09$
\end{tabular}

RBD: Regional Basic Diet; $\overline{\mathrm{X}}$ : arithmetic mean; SD: standard deviation.

TABLE II

Apparent and True Absorption Coefficients (non-protein biological assay and linear regression methods), in undernourished RBD-fed and well fed control mice infected or not with Schistosoma mansoni

\begin{tabular}{|c|c|c|c|c|}
\hline \multirow{2}{*}{ Groups } & \multirow{2}{*}{$\begin{array}{c}\text { Number } \\
\text { of } \\
\text { mice }\end{array}$} & \multicolumn{3}{|c|}{ Absorption coefficient } \\
\hline & & $\begin{array}{l}\text { Apparent } \\
(X \pm S D)\end{array}$ & $(\overline{\mathrm{X}} \pm \mathrm{SD})^{a}$ & $\begin{array}{c}\text { True } \\
(\bar{X} \pm \mathrm{SD})\end{array}$ \\
\hline $\begin{array}{l}\text { Casein (non-infected) } \\
\text { Casein (infected) }\end{array}$ & $\begin{array}{l}10 \\
10\end{array}$ & $\begin{array}{c}87.7 \pm 3.2 \\
85.6 \pm 6.1 \\
\text { Non-significant }\end{array}$ & $\begin{array}{c}92.4 \pm 3.6 \\
91.0 \pm 5.3 \\
\text { Non-significant }\end{array}$ & $\begin{array}{c}89.4 \pm 2.8 \\
86.6 \pm 5.9 \\
\text { Non-significant }\end{array}$ \\
\hline $\begin{array}{l}\text { RBD (non-infected) } \\
\text { RBD (infected) }\end{array}$ & $\begin{array}{l}10 \\
10\end{array}$ & $\begin{array}{c}46.8 \pm 12.8 \\
25.8 \pm 20.9 \\
\text { Significant }(p<0.01)\end{array}$ & $\begin{array}{c}54.9 \pm 11.4 \\
47.0 \pm 14.3 \\
\text { Non-significant }\end{array}$ & $\begin{array}{c}76.9 \pm 9.9 \\
58.8 \pm 13.5 \\
\text { Significant }(\mathrm{p}<0.01)\end{array}$ \\
\hline
\end{tabular}

RBD: Regional Basic Diet; $\bar{X}=$ Arithmetic mean; $\mathrm{SD}=$ Standard deviation.

True $a$ : values obtained for the True Absorption Coefficient when the fecal melabolic nitrogen was determined by using a non-protein fed group of mice (biological assay).

True $b$ : values obtained for the True Absorption Coefficient when a correction for the fecal metabolic nitrogen was made. Linear regression was calculated among the different levels of protein intake in relation to the excretion of fecal nitrogen detected for each animal from each group of mice, extrapolation being made to the point of protein intake $=$ zero.

\section{TABLE III}

Excretion of fecal metabolic nitrogen in undernourished and control mice according to the methods of feeding a non-protein diet (biological assay) and linear regression calculation

\begin{tabular}{lccc}
\hline Groups & Fecal metabolic nitrogen & & $\begin{array}{c}\text { Fecal metabolic nitrogen } \\
\text { (Biological assay) }\end{array}$ \\
Control & Non-infected & 0.015 & 0.005 \\
& Infected & $(5)$ & $(10)$ \\
& & 0.028 & 0.005 \\
Undernourished & Non-infected & $(5)$ & $(10)$ \\
& Infected & 0.009 & 0.035 \\
& & 0.011 & $(10)$ \\
& $(3)$ & & $(10)$ \\
\hline
\end{tabular}

$(\quad)=$ number of animals 
between the two casein-fed groups, but a higher excretion of FMN occurred in RBD-fed mice, particularly in the non-infected group (Table III).

\section{DISCUSSION}

Infected and non-infected control (caseinfed) mice had similar intestinal protein absorption ratios, according to the methods used in the present trial. Undernourished (RBD-fed) mice showed significantly lower values when compared to their controls, particularly the $S$. mansoni infected group. Malnutrition induced by RBD intake was responsible for some reduction in intestinal protein absorption, which was substantially aggravated by $S$. mansoni infection.

The use of a non-protein fed group for determination of the FMN and subsequent calculation of the TAC deserves some comments. The intake of a non-protein diet leads to a sudden suppression of the protein supply to the body, causing important changes in enzyme systems, in endocrine balance and in the supply of proteins to the blood, liver and other tissues and organs. The reduction of dietary protein supply interferes with the normal growth and metabolic activities of the animal and induces a more intensive protein catabolism, with undesirable effects on the metabolism of other body components (Chaves \& Rego Barros, 1962). For this reason, Holemans \& Lambrechts (1955), Waterlow \& Wills (1960) and other investigators recommend the method of extrapolation calculated through linear regression, for determination of the FMN and of the TAC.

In the present experiment, it is likely that the intake of a non-protein diet by animals exposed to different conditions (deficient diet, balanced diet, infection by $S$. mansoni) may induce a diversity of metabolic alterations, including the following: (a) undernourished mice ingesting a low protein diet (RBD) will be more able to adapt themselves to a protein deficiency status than well fed mice. These, however, would be able to subsist on a nonprotein diet for longer, due to their better body protein reserves; (b) infected animals have a greater excretion of metabolic nitrogen in the feces in view of their increased catabolism. The method using a non-protein diet for determination of FMN needs an extra batch of animals and thus it is more complicated and time-consuming. Besides its greater sensitivity, the method of extrapolation through linear regression is much simpler and easier.

The relationship between malnutrition and intestinal malabsorption syndrome is documented in the literature (Holemans \& Lambrechts, 1955; Lee \& Chow, 1965; Adibi, 1970; Walker-Smith \& McNeish, 1989). The use of different animal models and experimental designs probably account for some discrepancies.

De Witt reported (1957b) that the ability to digest and absorb dietary fats and proteins was decreased in $S$. mansoni infected mice fed a complete semisynthetic dry ration. In the present investigation, a reduced intestinal protein absorption was noticed in undernourished RBD-fed animals. Infection with $S$. mansoni had apparently no effect on intestinal protein absorption in casein-fed (control) animals. The different infective cercarial load (150 x 40) may account for the different results reported in Dewitt's paper as compared to our findings regarding well-fed mice. It was not possible to determine the factors involved in this malabsorption. One can speculate that an enzyme deficiency or microscopic alterations at the mucosal level of the small intestine may account for such disfunction.

As each nutrient has specific requirements for its absorption, generalizations may not be correct. In the particular case of schistosomiasis in association with malnutrition, however, it is likely that the absorption of other nutrients like lipids, for instance, can be impaired as a result of liver lesions, blood stasis due to portal hypertension, and deficient conjugation of biliary salts (Machado, 1988).

In schistosomiasis, portal hypertension develops in the severe chronic clinical form of the disease (hepato-splenic clinical form) and this would be responsible for the blood stasis and congestion in the vessels of the intestinal wall, changing the concentration and causing an unfavourable gradient to the absorption of nutrients (El-Rooby et al., 1963; Fikry et al., 1966). On the other hand, the integrity of the intestinal mucosa is fundamental for digestive and absorptive processes to take place (Nigro et al., 1984). Morphological changes have been found in the mucosal layer of the small intestine, in both malnutrition (Brunser et al., 1968; Waterlow \& Alleyne, 1971; Coutinho et al., 
1989) and schistosomiasis (Castro et al., 1971; Nigro et al., 1984; Fedail \& Gadir, 1985).

In conclusion, based upon our model, it seems that infection with $S$. mansoni interferes with the process of intestinal protein absorption by potentiating the negative effects of malnutrition on the jejunal mucosa, even in early schistosomiasis. In addition, one could speculate that in endemic areas of schistosomiasis mansoni in Northeast Brazil, where patients of low income classes usually show a poor nutritional status, the improvement of this condition in populations with low infection rates could be, as mass treatment, more beneficial to this kind of patient than chemotherapy.

\section{REFERENCES}

ADIBI, S. A., 1970. Impaired jejunal absorption rates of essential aminoacids induced by either dietary caloric or protein deprivations in man. Gastroenterology, 59: 404-413.

AKPOM, C. A. \& WARREN, K. S., 1975. Calorie and Protein malnutrition in chronic murine Schistosomiasis mansoni: effect on the parasite and the host. J. Infect. Dis., 132: 6-14.

BRUNSER, O.; REID, A.; MONCKEBERG, F.; MACCIONI, A. \& CONTRERAS, I., 1968. Jejunal mucosa in infant malnutrition. Am. J. Clin. Nutrit., 21: 976-983.

CASTRO, L. P.; DANI, R.; ALWARENGA, R. J.; CHAMONE, D. A. F. \& OLIVEIRA, C. A., 1971. A peroral biopsy study of the jejunum in human schistosomiasis mansoni. Rev. Inst. Med. Trop. São Paulo, 13: 103-109.

CHAVES, N. F. C. \& REGO BARROS, M. M., 1962. Métodos de estudo das proteinas. Arq. Bras. Endocrinol. Metabol., 11: 55-70.

COUTINHO, E. M., 1976. Relaçöes hospedeiro-parasito na esquistossomose mansônica, em função da Dieta Básica Regional (Estudo epidemiológico e anátomopatologico). PhD Thesis, Universidade Federal de Pernambuco, Brazil, 109 p.

COUTINHO, E. M., 1980. Patobiologia da desnutrição nas doenças parasitárias. Mem. Inst. Oswaldo Cruz, 75: 63-76.

COUTINHO, E. M.; ABATH, F. G. C.; FREITAS, L. P. C. G.; SALZANO, A. C,; LAPA, M. A.; CAMPOS, F. S. \& MELO, E. B., 1991. Liver and serum soluble protein changes and pathomorphology in undernourished mice with acute schistosomiasis mansoni. Rev. Soc. Bras. Med. Trop., 24: 235-243.

COUTINHO, E. M.; FREITAS, L. P. C. G. \& ABATH, F. G. C., 1992. The influence of the Regional Basic Diet from Northeast Brazil on health and nutritional conditions of mice infected with Schistosoma mansoni. Rev. Soc. Bras. Med. Trop., 25: 13-20.

COUTINHO, E. M.; MAGALHÃES FILHO, A. \& BARBOSA, J. M., 1962. Lesões hepáticas no camundongo albino experimentalmente infestado por $S$. mansoni e submetido a dietas de diferente teor protéico. Rev. Inst. Med. Trop. São Paulo, 4: 311 322.

COUTINHO, E. M.; PADOVAN, I.; CARVALHO, G. L.; PADOVAN, P. A.; PADILHA, R. J. R. \& GOMES, L. P., 1989. Scanning electron microscopy of the small intestine mucosa in mice fed the Regional Basic Diet from Northeast Brazil (Preliminary data). In Colóquio da Sociedade Brasileira de Microscopia Eletrônica, 12, vol. I., Caxambu Anais, p. 49-50.

DE WITT, W. B., 1957a. Experimental schistosomiasis mansoni in mice maintained on nutritionally deficient diets. 1 - Effects of a Torula yeast ration deficient in factor 3 , vitamin $\mathrm{E}$, and cystine. $J$. Parasitol., 43: 119-128.

DE WITT, W. B., 1957b. Effects of Schistosoma mansoni infections on the ability of mice to digest and absorb dietary fats and proteins. J. Parasitol., 43: 32.

EL-ROOBY, A.; GAD-EL-MAWLA, N.; GALIL, N.; ABDALLA, A. \& SHAKIR, M., 1963. Studies on the malabsorption syndrome among egyptians. II Malabsorption in bilharzial hepatic fibrosis. J. Egypt. Med. Assoc., 46: 777-782.

FEDAIL, S. S. \& GADIR, A. F. M. A., 1985. The pathology of the small intestine in human Schistosomiasis mansoni in the Sudan. Trop. Med. Parasitol., 36: 94-96.

FIKRY, M. E., 1963. Disturbances of digestion and absorption in bilharzial hepatic fibrosis. $J$. Trop. Med. Hyg., 66: 213-215.

FIKRY, M. E.; HANNO, M. G.; EL-SAYED, M. \& DORRY, K., 1966. The Iodol31 triolein intestinal absorption test in schistosomal (bilharzial) hepatic fibrosis patients. Acta Gastroenterol. Belgian, 29: 99-104.

GUEDES, R C. A.; ANDRADE, A. F. D. \& CABRAL FILHO, J. E., 1987. Propagation of cortical spreading depression in malnourished rats: facilitatory effects of dietary protein deficiency. Braz. J. Med. Biol. Res., 20: 639-642.

HOLEMANS, K. \& LAMBRECHTS, A., 1955. Nitrogen metabolism and fat absorption in malnutrition and in Kwashiorkor. J. Nutrit., 56: 477-494.

KNAUFT, R. F. \& WARREN, K. S., 1969. The effect of Calorie and Protein malnutrition on both the parasite and the host in acute murine Schistosomiasis mansoni. J. Infect. Dis., I20: 560-575.

LAGO, E. S.; PESSOA, D. C. N. P.; TEODóSIO, N. R. \& CABRAL FILHO, J. E., 1988. Longevity and growth curve of chronically malnourished rats fed the Regional Basic Diet (RBD). In Abstract of the 2nd. Intemational Symposium of Nutrition, Proceedings, p. 40-41, Recife, Brazil.

LEE, C. J. \& CHOW, B. F., 1965. Protein metabolism in the offspring of underfed mother rats. J. Nutrit., 87 : 439-443.

MACHADO, R. J. C., 1988. Estudo da absorção e da mucosa do intestino delgado de esquistossomóticos hepatoesplénicos, antes e após esplenectomia mais ligadura de varizes esofageanas. PhD Thesis, Universidade de São Paulo, São Paulo, Brazil, 91 p.

MOTT, C. B.; NEVES, D. P. \& BETTARELLO, A., 1971. Absorção intestinal na forma hepatoesplênica da esquistossomose mansônica. Rev. Hosp. Clin. Fac. Med. São Paulo, 26: 55-60. 
NIGRO, S. P.; MISZPUTEN, S.; HAYASHI, H. \& SAAD, F. A., 1984. Estudo morfométrico da mucosa jejunal na esquistossomose mansônica humana. Rev. Assoc. Med. Bras., 30: 61-63.

PUCCI, H.; VILELA, M. P.; MISZPUTEN, S. J.; CARVALHO, N.; SECAF, F. \& SAAD, F. A., 1978. Estudo da absorção intestinal de gorduras na esquistossomose mansônica humana. Rev. Assoc. Med. Bras., 24: 341-344.

SILVA, A. T.; COSTA, F. B. R.; COSTA, J. A.; TEODOSIO, N. R; CABRAL FILHO, J. E. \& GUEDES, R. C. A., 1987. Sciatic nerve conduction velocity of malnourished rats fed the human "Basic Regional Diet" of the northeast of Brazil. Braz. J. Med. Biol. Res., 20: 383-392.

TAGLE, M. A. \& DONOSO, G., 1965. Net protein utilization determined in short and long-term ex- periments with rats. $J$. Nutrit., 87: 173-178.

TEODÓSIO, N. R; LAGO, E. S.; ROMANI, S. A. M. \& GUEDES, R. C. A., 1990. A regional basic diet from Northeast Brazil as a dietary model of experimental malnutrition. Arch. Lat. Amer. Nutr., 40:533-547.

WALKER-SMITH, J. A. \& McNEISH, A., 1989. Diarréia e desnutrição na infância. Ed. Revinter, Rio de Janeiro, 272 p.

WATERLOW, J. C. \& ALLEYNE, G. A. O., 1971. Protein malnutrition in children: advances in knowledge in the last ten years. p. 177-241. In Advances in Protein Chemistry, vol. 25, Academic Press Inc., New York.

WATERLOW, J. C. \& WLLLS, V. G., 1960. Balance studies in malnourished jamaican infants. 1. Absorption and retention of Nitrogen and Phosphorus. Brit. J. Nutrit., 14: 183-198. 